Witold Mańczak

Uniwersytet Jagielloński

\title{
O pochodzeniu nazwy Polski
}

Spośród wszystkich nazw geograficznych występujących w naszym kraju najczęściej używana jest nazwa Polski. Jej pochodzeniu poświęcam niniejszy artykuł. Chodzi mianowicie o to, że w roku 2008 znany archeolog Przemysław Urbańczyk wydał książkę pt. Trudne początki Polski, na obwolucie której czytamy, że „książka jest próbą podjęcia krytycznej dyskusji z wieloma utrwalonymi poglądami na początki polskiej państwowości. Dotyczy to m.in. tak newralgicznych zagadnień, jak: wiarygodność istnienia plemion Polan i Wiślan, początki polskich miast, identyfikacja stolicy państwa wczesnopiastowskiego i jego granic, interpretacja Zjazdu Gnieźnieńskiego oraz pochodzenia nazw Polska i Polacy”.

Jeśli chodzi o ostatnią kwestię, P. Urbańczyk sądzi, że ,zarówno Lechici wymyśleni przez Mistrza Wincentego, jak i plemię Polan, które miało rzekomo utworzyć «polskie» państwo, są wytworami «narodowego» pojmowania dziejów" [Urbańczyk 2008: 59]. Według P. Urbańczyka „najpierw wprowadzono ogólnopaństwową nazwę Polonia i dopiero później względy praktyczne wymusiły wprowadzenie podziałów wewnętrznych. Poszukiwanie korzeni Wielkopolski, Małopolski, Śląska, Mazowsza, Kujaw czy Pomorza w jakichś czasach «plemiennych» jest więc próbą odwrócenia procesu historycznego" [ibidem: 359]. Zdaniem warszawskiego archeologa „to nie od plemienia Polan pochodzą nazwy państwa i poddanych Bolesława Chrobrego, lecz wręcz przeciwnie - to «Polanie» są późnym produktem etymologizujących wysiłków średniowiecznych kronikarzy, próbujących zracjonalizować znaczenie «obco» brzmiącej, bo od początku zlatynizowanej nazwy Poloni, która miała znaczenie polityczne, a nie etniczne" [ibidem: 360]. W przekonaniu autora opracowania „wybór choronimu Polonia świadczy o tym, że żadni Polanie nigdy nie istnieli jako wyróżnialny etnos. Z polityczno-pragmatycznego punktu widzenia nawiązanie do jakiegoś starszego etnonimu lokalnego byłoby bowiem niewiarygodnym samoograniczeniem i utrudniałoby ideologiczną integrację zróżnicowanego kulturowo obszaru we wspólnotę etnopolityczną. Odwołanie się do jednej tylko tradycji etnicznej utrudniłoby proces ponadlokalnej identyfikacji. [...] «administracyjne» narzucenie wspólnej ponadetnicznej nazwy było więc politycznym symbolem wewnętrznego programu zjednoczeniowego" [ibidem: 358]. 
Wszystko to pozostaje w rażącej sprzeczności z wynikami badań onomastycznych, które wykazują powszechną tendencję polegającą na tym, że nazwy terytoriów z reguły rozszerzają swoje znaczenie. Przykładowo, jedno z lotnisk paryskich nazywa się Roissy-en-France. W nazwie tej wyraz France nie oznacza dzisiejszej Francji, ale się odnosi do małego obszaru zwanego za naszych czasów Île-de-France, gdzie rzeki Marna i Oise wpadają do Sekwany. Tak więc zasięg nazwy France uległ ogromnemu rozszerzeniu.

Podobnie nazwa Śląsk pierwotnie oznaczała niewielki obszar położony w sąsiedztwie rzeki Ślęzy i góry Ślęży. A więc i tu doszło do znacznego rozszerzenia znaczenia tej nazwy geograficznej.

Kolejnym przykładem niech będzie niewielki skrawek dzisiejszej Szwecji, który się zowie Roslagen. Od pierwszego członu tej nazwy złożonej (Ros-) pochodzi fińska nazwa Szwecji Ruotsi, z kolei od fińskiego Ruotsi wywodzi się nazwa Rusi, a od niej nazwa Rosji, największego państwa na świecie, rozpościerającego się od Morza Bałtyckiego po Cieśninę Beringa.

Nazwa Portugalii związana jest z nazwą miasta Porto (od której pochodzi też nazwa wina porto). Miasto to, położone na północ od Lizbony u ujścia rzeki Douro do Oceanu Atlantyckiego, zwało się w starożytności portus Cale, a nazwa ta rozszerzona została najpierw na okolice miasta, a w końcu na cały kraj.

Włochy nazywają się po włosku Italia, a nazwa ta pierwotnie oznaczała najbardziej południowy skrawek Półwyspu Apenińskiego, doznawszy zaś kilkakrotnie rozszerzenia znaczenia, już w starożytności nabrała znaczenia niemal dzisiejszego.

Nazwa Indii pochodzi od sanskryckiego słowa sindhu 'rzeka'. Wyrazu tego zaczęto używać na oznaczenie wielkiej rzeki zachodniego Hindustanu, a następnie krainy położonej nad dolnym Indusem. Kraj ten podbili władcy perscy z dynastii Achemenidów, a w wymowie irańskiej z Sindhu powstało Hindu. Nazwę tę, pierwotnie odnoszącą się do dorzecza Indusu, później rozszerzono na dorzecza Gangesu i Brahmaputry, a w końcu Indiami zaczęto nazywać cały subkontynent położony na południe od Himalajów.

Łaciński choronim Africa pierwotnie oznaczał rzymską prowincję, która stanowiła przeciwległe wybrzeże Sycylii. Później ta nazwa zaczęła oznaczać jedną z kontynentalnych części świata.

Grecy Azja pierwotnie nazywali lidyjskie wybrzeże Azji Mniejszej. Ostatecznie nazwa ta stała się nazwą ogromnego kontynentu.

U Herodota Europa oznacza krainę położoną na północ od Morza Egejskiego w przeciwstawieniu do Peloponezu i Wysp Egejskich. Ostatecznie nazwa ta zaczęła oznaczać jedną z części świata.

Nazwa Finlandii pierwotnie odnosiła się do jej południowo-zachodniej części, a dopiero później doszło do jej rozszerzenia na obszar dzisiejszy.

Nazwa Syberii pierwotnie się odnosiła do tzw. Kraju Tobolskiego, a później zaczęła oznaczać niemal całą północną Azję. 
W świetle tych przykładów, których ilość można by łatwo pomnożyć, nie ulega wątpliwości, że nazwa Polska pierwotnie oznaczała ziemię Polan, a dopiero później doznała rozszerzenia znaczenia, odnosząc się np. do terytorium państwa Bolesława Chrobrego.

Trzeba jeszcze wrócić do cytatu z obwoluty książki P. Urbańczyka: „Książka jest próbą podjęcia krytycznej dyskusji z wieloma utrwalonymi poglądami na początki polskiej państwowości. Dotyczy to m.in. tak newralgicznych zagadnień, jak: wiarygodność istnienia plemion Polan i Wiślan”. Jeśli chodzi o Wiślan, należy podkreślić, że nazwa Wiślanie pojawia się w IX w. w trzech niezależnych od siebie źródłach, a mianowicie u Geografa Bawarskiego, w opisie Germanii sporządzonym przez anglosaskiego króla Alfreda Wielkiego oraz w anonimowym żywocie św. Metodego. Otóż jest bardzo ważne, że P. Urbańczyk nie przytacza żadnego argumentu na poparcie tezy, jakoby te trzy przekazy nie były „,wiarygodne”.

Na stronach 359-360 P. Urbańczyk pisze, że ,gdyby Chrobry uważał się za księcia Polan, to bez najmniejszej wątpliwości wybrałby dla swojego państwa nazwę Polania, a nie Polonia". Warszawski archeolog ma na myśli denar z czasów Bolesława Chrobrego, na którym nasz władca określany jest jako dux Poloniae. W związku z tym należy podkreślić, że Bolesław Chrobry był analfabetą i nie znał łaciny, a cudzoziemiec kierujący jego mennicą, chociaż zapewne znał się na swoim rzemiośle, to mało prawdopodobne jest, żeby równocześnie był obdarzony uzdolnieniami językoznawczymi, które by go skłaniały do rozważań nad łacińską nazwą państwa polskiego księcia. Warto też uwzględnić fakt, że w średniowiecznej łacińskiej terminologii geograficznej nazwy typu Saxonia były nieco częstsze od nazw typu Campania. Policzyłem, że w pierwszym tomie Monumenta Poloniae Historica nazwy na -onia były zaświadczone 51 razy, a nazwy na -ania - 44 razy i to też mogło być przyczyną tego, że nazwa naszego kraju utrwaliła się jako Polonia.

Swoje rozważania na temat pochodzenia nazw Polska i Polacy P. Urbańczyk kończy następującym wyznaniem: „Ja, w każdym razie, godzę się z mało «patriotyczną» konkluzją, że nasz narodowy etnonim choć miał «polskie» pochodzenie, to został oficjalnie przyjęty pod wpływem faktów dokonanych wcześniej za granicą" [Urbańczyk 2008: 359]. Wypadki, że sąsiedzi nazywają jakiś lud inaczej, niż on sam siebie nazywa, nieraz się zdarzają. Daleko nie szukając, wystarczy wspomnieć o tym, że nasi zachodni sąsiedzi sami siebie nazywają Deutsche, ale my - podobnie jak i inni Słowianie - nazywamy ich Niemcami, a odpowiednikiem polskiego przymiotnika niemiecki jest fr. allemand, ang. German, fińskie saksalainen (dosłownie 'saski') czy litewskie vokiškas (o niejasnej etymologii). Jednak wypadki, żeby jakaś grupa etniczna nazywała siebie etnonimem nie rodzimym, ale utworzonym przez inną grupę etniczną, są niesłychanie rzadkie, a w ogóle możliwe jest to tylko wtedy, gdy jakaś ludność ulega ogromnemu wpływowi innego języka. Jako przykład można przytoczyć kilkunastotysięczną wspólnotę językową zamieszkałą w Grecji, w okolicach Salonik, którą językoznawcy nazywają Meglenorumunami, a oni sami określają się jako Vlaši (tzn. Wołosi). Jednak 
należy sobie uświadomić, że sytuacja naszych przodków za pierwszych Piastów była absolutnie nieporównywalna z sytuacją nielicznych Meglenorumunów, którzy nieustannie stykają się z ludnością obcą i na skutek tego są dwu- lub nawet trójjęzyczni. Dlatego nie jestem w stanie uwierzyć w twierdzenie P. Urbańczyka, jakoby łacińskie nazwy Polonia i Poloni powstały wcześniej od polskich nazw Polski i Polan.

Ponadto należy zwrócić uwagę na jeszcze jeden poważny mankament koncepcji P. Urbańczyka. Chodzi mianowicie o to, że w artykule opublikowanym kilka lat wcześniej [Urbańczyk 2010: 362] archeolog powiada, że łacińskie nazwy Poloni / Polani oraz Polonia / Polania są „o oczywiście słowiańskim źródłosłowie", ale nie ujawnia, jaka jest ich etymologia. Autor nieustannie powtarza, że nazwy Poloni i Polonia nie mają nic wspólnego z nazwą plemienia Polan, ale przemilcza sprawę o kapitalnym znaczeniu, a mianowicie kwestię, że jeśli nazwy Poloni i Polonia nie wywodzą się od nazwy Polan, to od jakiego innego wyrazu słowiańskiego one pochodzą.

Na zakończenie warto wspomnieć jeszcze o jednym. Zanim się ukazała jego książka, P. Urbańczyk w „Gazecie Wyborczej” z 25 maja 2008 r. zamieścił artykuł, w którym pokrótce przedstawił swe poglądy na pochodzenie nazw Polski i Polaków. Na ten artykuł zareagował Gerard Labuda, nestor polskich historyków, odpowiedzią pod znamiennym tytułem Nie było żadnych Polon / Polonów, byli Polanie i przesłał ją do „Gazety Wyborczej” w grudniu 2008 r. Jednak według słów poznańskiego historyka „mimo wielokrotnych monitów redakcja «GW» wstrzymywała się od jej publikacji”. W końcu nieżyjący już dziś G. Labuda nie miał innego wyjścia jak opublikować swą odpowiedź w listopadzie 2009 r. w czasopiśmie „Mówią Wieki” [nr 598, s. 24-27], a więc w piśmie, którego nakład jest znikomy w porównaniu z nakładem „Gazety Wyborczej”.

Nie wyobrażam sobie, żeby redakcja „Gazety Wyborczej”, która odmówiła zamieszczenia artykułu jednemu z najwybitniejszych historyków polskich, jakim był G. Labuda, uczyniła to wyłącznie z własnej inicjatywy. Jest wysoce prawdopodobne, że w tej sprawie zadziałał P. Urbańczyk, i to tym bardziej, że wśród dzisiejszych archeologów polskich takie postępowanie jest bardzo rozpowszechnione. Większość dzisiejszych archeologów polskich usiłuje per fas et nefas przeforsować tezę Godłowskiego o naddnieprzańskiej praojczyźnie Słowian, przy czym przeciwników tej koncepcji nie dopuszcza do głosu [Mańczak 2004: 43]. Osobiście należę do tych, którzy sądzą, że nauka może się rozwijać jedynie w atmosferze zupełnie swobodnej dyskusji. Dlatego uważam, że P. Urbańczyk, jeśli nie dopuścił do zamieszczenia odpowiedzi G. Labudy w „Gazecie Wyborczej”, postąpił nieuczciwie. 


\section{Bibliografia}

Labuda Gerard, 2009, „Mówią Wieki” nr 598: 24-27.

Mańczak Witold, 2004, Przedhistoryczne migracje Stowian i pochodzenie języka staro-cerkiewno-stowiańskiego, Kraków.

Urbańczyk Przemysław, 2008, Trudne początki Polski, Wrocław.

Urbańczyk Przemysław, 2010, Onomastyka a „sprawa polska”, „Prace Komisji Nauk Filologicznych Oddz. PAN we Wrocławiu" II, 259-364.

Witold Mańczak

\section{About the etymology of the name Polska}

\section{(Summary)}

The text presents an opinion in the discussion on the etymology of the choronym Polska / Polonia. The author argues with Przemysław Urbańczyk, who claims that the name of Polons and Polonia has no connection with the tribe of Polans. On the contrary the opinion presented in the article maintains the historical truth according to which the Polans, whose name was mentioned, spread in the larger territory than the region inhabited originally by them. The author cites other similar examples in the history of tribes, nations and the formation of their denominative identity.

Słowa kluczowe: Polska, choronim, toponimia, etymologia.

Key words: Polska, choronym, toponymy, etymology. 